\title{
PERANAN SEKOLAH DALAM MEMBENTUK KARAKTER RELIGIUS DAN DISIPLIN PESERTA DIDIK
}

\author{
Wida Dwi Aryanti \\ FKIP Universitas Muhammadiyah Malang, Indonesia \\ Email:widadwia@gmail.com
}

\begin{abstract}
ABSTRAK
Penelitian ini bertujuan untuk: (1) mengetahui program pendidikan karakter religius yang dikembangkan di SMAN 2 Batu. (2) mengetahui program pendidikan karakter disiplin yang dikembangkan di SMAN 2 Batu. (3) mendeskripsikan bentuk implementasi dari karakter religius dan disiplin peserta didik di SMAN 2 Batu. Metode Penelitian yang digunakan adalah pendekatan penelitian deskriptif. Hasil penelitian menunjukan bahwa: (1) program pendidikan karakter religius seperti: Keputrian, BTQ, infak, sholat berjamaah, perayaan hari-hari besar, dan lain-lain, (2) program karakter disiplin, seperti: Pengenalan lingkungan sekolah, baris-berbaris, seluruh aturan tata tertib, dan lain-lain, program-program tersebut merupakan cara yang efisien untuk membentuk karakter religius dan disiplin peserta didik di SMAN 2 Batu. (3) Bentuk implementasi dari karakter religius dan disiplin peserta didik di SMAN 2 Batu dengan memberikan internalisasi pendidikan karakter religius dan disiplin, membiasakan peserta didik untuk mengikuti seluruh program yang telah dibuat khususnya program religius dan disiplin, memberikan teladan yang baik untuk peserta didik, serta memaksukkan faktor-faktor yang mempengaruhi karakter religius dan disiplin, seperti faktor intern dan faktor ekstern peserta didik.
\end{abstract}

Kata Kunci: Karakter Disiplin; Karakter Religius; Peranan Sekolah

\begin{abstract}
Hence this research aim to: (1) know the education program of religious character developed in SMAN 2 Batu. (2) to know the character education program of discipline developed in SMAN 2 Batu. (3) to describe the implementation of the religious character and discipline of learners in SMAN 2 Batu. The research method used is descriptive research approach. The results of the study show that: (1) religious character education programs such as: Keputrian, BTQ, infaq, congregational prayer, celebration of big days, etc. (2) disciplinary character program, such as: Introduction of school environment, , the entire rules of order, etc., the programs are an efficient way to shape the religious and disciplinary character of students in SMAN 2 Batu. (3) The form of implementation of the religious character and discipline of students in SMAN 2 Batu by providing internalization of religious character education and discipline, familiarize the students to follow all the programs that have been made especially religious and discipline program, to set a good example for students, as well implies factors that affect religious character and discipline, such as internal factors and external factors students.
\end{abstract}

Keywords : Character of Discipline; Character of Religious; The Role of School

\section{PENDAHULUAN}

Indonesia sedang sibuk menerapkan

sistem pendidikan karakter guna mendidik para generasi penerus bangsa menjadi manusia yang berkarakter. Pendidikan karakter dilaksanakan dengan menanamkan nilai-nilai karakter pada setiap matapelajaran maupun matakuliah yang diajarkan oleh semua instansi pendidikan kepada para peserta didik maupun mahasiswa. Menurut Kementrian Pendidikan Nasional (2010) terdapat 18 nilai karakter yang ditanamkan dalam pendidikan karakter, salah satunya adalah religius dan disiplin.

Pendidikan Karakter di Indonesia seharusnya tidak hanya fokus pada perbaikan sikap atau tingkah laku generasi 
muda, akan tetapi juga memperkuat nilainilai keagamaan yang berbasis spiritual dan toleran. Pendapat tentang pendidikan karakter menurut T. Ramli (2003) Pendidikan Karakter memiliki esensi dan makna yang sama dengan pendidikan moral dan pendidikan akhlak, tujuannya adalah untuk membentuk pribadi anak supaya menjadi manusia yang baik, warga masyarakat dan warga negara yang baik. Pendidikan Karakter bukan merupakan sesuatu yang baru di Negeri ini, namun dalam implementasinya sikap dan tingkah laku generasi muda saat ini begitu jauh menyimpang dari yang diajarkan dalam pendidikan sekolah. Inilah yang menjadi PR bagi guru dan instansi terkait untuk berfikir ekstra dalam menanggulangi permasalahan yang terjadi pada generasi penerus bangsa dan mampu menyelesaikan problem moralitas dan krisis karakter pada generasi muda.

Padahal sudahjelas tujuan pendidikan sendiri sebagaimana amanat UndangUndang Sistem Pendidikan Nasional (UU Sisdiknas No. 20 tahun 2003) dalam pasal 3 ditegaskan bahwa:

"mengembangkan kemampuan dan
membentuk watak serta peradaban
bangsa yang bermartabat dalam
rangka mencerdaskan kehidupan
bangsa, bertujuan mengembangkan
potensi peserta didik agar menjadi
manusia yang beriman dan
bertakwa kepada Tuhan Yang Maha
Esa, berahklakmulia, sehat, berilmu,
cakap, kreatif, mandiri, dan menjadi
warga negara yang demokratis serta
bertanggung jawab."

Dari persoalan yang telah dipaparkan diatas, masalah yang perlu disoroti adalah pelaksanaan Pendidikan Karakter yang dilakukan oleh sekolah, entah itu dari pihak pendidik atau yang dididik, karena pendidikan disekolah merupakan tonggak awal untuk menyadarkan peserta didik tentang pentingnya Pendidikan Karakter. Di SMAN 2 Batu 5 tahun yang lalu adalah sekolah yang dikenal sekolah yang kurang baik, karena memang dulu sekolah ini kurang populer daripada sekolah lain yang lebih dipilih masyarakat, kebanyakan peserta didik yang sekolah di SMAN 2 Batu adalah peserta didik yang tidak diterima di sekolah yang terbaik saat itu, ada juga peserta didik yang masuk SMAN 2 Batu karena kurangnya biaya dari orang tua untuk menyekolahkan anaknya di SMA yang lebih baik, bahkan ada dari masyarakat yang berkata "seng penting sekolah" dari hasil wawancara dengan salah satu guru di SMAN 2 Batu. Maka dari itu banyak peserta didik yang heterogen yang perlu di perbaiki pemikirannya tentang pentingnya pendidikan. Namun SMAN 2 Batu tidak mau berlama-lama dalam keterpurukan, maka dari itu SMAN 2 Batu berusaha mengembangkan banyak program-program yang mendorong peserta didik agar berkarakter, lebih khususnya berkarakter religius dan disiplin. Dan akhirnya setelah bertahun-tahun melalui banyak kendala akhirnya SMAN 2 Batu dapat tersenyum lebar dengan usaha yang tidak mudah dan dapat akhirnya dapat benar-benar mengimplementasikan Visinya, yaitu "Sekolah Unggul Prestasi, Berbudaya, Berakhlak Dan Berdaya Saing Berlandaskan Iman dan Taqwa”. Oleh karena itu peneliti mengangkat judul "Peranan Sekolah dalam Membentuk Karakter Religius dan Disiplin Peserta Didik di SMAN 2 Batu" yang harapannya dapat menjadi pedoman bagi guru dan instansi terkait dalam mengatasi persoalan tentang penurunan karakter.

Untuk memperbaiki karakter peserta didik khususnya karakter religius dan disiplin, maka penelitian ini bertujuan untuk: (1) mengetahui program pendidikan karakter religius yang dikembangkan di SMAN 2 Batu. (2) mengetahui program 
pendidikan karakter disiplin yang dikembangkan di SMAN 2 Batu. (3) mendeskripsikan bentuk implementasi dari karakter religius dan disiplin peserta didik di SMAN 2 Batu.

Menurut Puskurbuk (2011) dalam Zuriah (2017) ada 18 (delapan belas) nilai-nilai pendidikan karakter yang bersumber dari Pancasila, budaya, agama, dan tujuan pendidikan nasional, meliputi: (1) Religius, (2) Jujur, (3) Toleransi, (4) Disiplin, (5) Kerja keras, (6) Kreatif, (7) Mandiri, (8) Demokratis, (9) Rasa Ingin Tahu, (10) Semangat Kebangsaan, (11) Cinta Tanah Air, (12) Menghargai Prestasi, (13) Bersahabat/ Komunikatif, (14) Cinta Damai, (15) Gemar Membaca,(16) Peduli Lingkungan, (17) Peduli Sosial, dan (18) Tanggung Jawab.

Dalam hal ini untuk mempermudah dalam pelaksanaan Penguatan Pendidikan Karakter ini Gerakan PPK ini mengkerucutkan 18 nilai karakter tersebut menjadi lima nilai utama karakter yang saling berkaitan. Kelima nilai utama karakter bangsa yang dimaksud adalah: Religius, Nasionalis, Mandiri, Gotong Royong dan Integritas (RENAMAGI) (Zuriah, 2017).

Menurut Lickona (1992), yang menegaskan bahwa karakter merupakan sifat alami seseorang dalam merespon situasi secara bermoral. Sifat alami tersebut diimplementasikan dalam tindakan nyata melalui tingkah laku yang baik, jujur, bertanggung jawab, adil, menghormati orang lain, disiplin, dan karakter luhur lainnya.

Menurut Hidayatullah (2010) mengatakan pendidikan karakter religius mengacu pada nilai-nilai dasar yang terdapat dalam agama (islam). Dalam pendidikan karakter ada banyak sumber, keteladanan Rasulullah Shallallahu Alaihi Wassalam adalah salah satu diantara nilainilai yang dapat dijadikan sumber dalam sikap dan perilaku sehari-hari beliau, yaitu shiddiq (jujur), amanah (dipercaya), tabligh (menyampaikan dengan transparan), dan fathanah (cerdas).

Karakter religius yang dideskripsikan oleh Suparlan (2010) sebagai salah satu nilai religius sebagai sikap dan perilaku yang patuh dalam melaksanakan ajaran agama yang dianut, toleran terhadap pelaksanaan ibadah agama lain, dan hidup rukun dengan pemeluk agama lain.

Dalam perkembangan sikap keagamaan ada beberapa faktor yang akan dibahas dengan jelas dalam pembahasan ini, Thouless (1971) menyebutkan beberapa faktor yang mempengaruhi karakter religius, yaitu:

a. Pengaruh pengajaran atau pendidikan serta bebagai tekanan sosial (faktor sosial).

b. Banyaknya pengalaman, khususnya pengalaman tentang:

1) Faktor Kebaikan, keselarasan, dan keindahan

2) Faktor moral yaitu Konflik moral

3) Pengalaman emosional keagamaan (faktor afektif)

c. Faktor yang muncul saat kebutuhan yang dibutuhkan tidak terpenuhi, khususnya pada kebutuhan sebagai berikut:

(1) cinta kasih, (2) harga diri, (3) ancaman, dan (4) keamanan.

d. Faktor Intelektual atau berbagai proses pemikiran verbal.

Menurut Syaiful Bahri Djamarah (2002), disiplin adalah suatu tata tertib yang dapat mengatur tatanan kehidupan pribadi dan kelompok.

Pendapat Subari (1994), mengatakan bahwa disiplin adalah penurutan terhadap suatu peraturan dengan kesadaran sendiri untuk terciptanya tujuan peraturan itu.

Karakter Disiplin itu terbentuk dari keadaan diamana orang yang tunduk pada peraturan dengan senang hati, dan tidak lepas dari faktor-faktor yang mempengaruhinya, yaitu faktor intern yang terdapat dalam diri orang yang bersangkutan yaitu: Faktor Pembawaan, Faktor Kesadaran, Faktor Minat dan Motivasi, dan Faktor Pengaruh 
Pola Pikir. Dan juga faktor ekstern yaitu faktor yang berada di luar diri orang yang bersangkutan yaitu: Contoh atau Teladan, Nasihat, Faktor Latihan, Faktor Lingkungan, dan Faktor Pengaruh Kelompok.

\section{METODE}

Metode Penelitian yang digunakan adalah pendekatan penelitian deskriptif, tempat dan waktu penelitian di SMAN 2 Batu selama 4 minggu. Prosedur Penelitian: Tahap pra lapangan, Tahap pelaksanaan / proses lapangan, Tahap analisa data, Tahap kesimpulan, dan Tahap pelaporan. Data Primer hasil wawancara, Data Skunder adalah buku, jurnal, data-data sekolah, sumber datanya adalah kepala sekolah, wakil kepala sekolah, guru agama, petugas tatib, dan beberapa peserta didik dari kelas XI IPA, IPS, dan IBBu. Teknik Pengumpulan datanya menggunakan wawancara, observasi, dan dokumentasi. Instrumen penelitian: Peneliti sebagai alat utama (Key Instrumen), Instrumen Observasi, Instrumen Wawancara, dan Instrumen Dokumentasi. Teknik Analisis data: Pengumpulan data, Reduksi Data, Penyajian data, dan Kesimpulan.

\section{HASIL DAN PEMBAHASAN Program Pendidikan Karakter Religius yang Dikembangkan Di SMAN 2 Batu}

Berdasarkan hasil penelitian yang telah dijelaskan pada analisis data diatas, maka didapatkan program-program yang dikembangkan di SMAN 2 Batu adalah: Berdoa sebelum melakukan pembelajaran, Penyambutan siswa, BTQ, keputrian, sholat berjamaah, infaq/shodaqoh, wisroh (wisata rohani islam), pekan seni PAI, sanlat (pesantren kilat), baksos pantiasuhan, manasik haji(setahun sekali), kantin kejujuran, qiroah, banjari/rebana, BD (Badan Dakwah), Adiwiyata, peringatan hari besar agama seperti idul adha, idul fitri, halal bihalal, isra' miraj, dan pendalaman tentang agama oleh guru-guru mata pelajaran.
Seperti yang dikatakan Hidayatullah (2010) pendidikan karakter religius mengacu pada nilai-nilai dasar yang terdapat dalam agama (islam), yaitu:

a. shiddiq (jujur) karakter ini bisa didapatkan dengan adanya kantin kejujuran yang dikembangkan di SMAN 2 Batu,

b. amanah (dipercaya) karakter ini bisa didapat saat mendapatkan materi pada program khutbah jum'at, program keputrian, dan sanlat,

c. tabligh (menyampaikan dengan transparan) karakter ini bisa didapatkan saat program BTQ saat ada sesi tanya jawab,

d. fathanah (cerdas) karakter ini bisa didapatkan saat program pekan seni PAI.

Dalam teori yang dijelaskan oleh Suparlan (2010), tentang karakter religius adalah sikap dan perilaku yang patuh dalam melaksanakan ajaran agama yang dianut, hidup rukun dengan pemeluk agama lain, dan toleran terhadap pelaksanaan ibadah agama lain. Dalam obervasi yang dilakukan peneliti pesera didik patuh untuk mengikuti kegiatan keagamaan yang diadakan oleh sekolah, dan juga toleran dan hidup rukun dengn pemeluk agama lain, seperti kasus dibawah ini.

Karena mayoritas di SMAN 2 Batu beragama islam maka lebih banyak mengadakan program yang ada dalam agama islam, namun juga ada beberapa program keagamaan selain islam seperti: BDK (Badan Dakwah Kristen), BDH (Badan Dakwah Hindu), dan BDB (Badan Dakwah Budha). Dalam kegitannya program-program ini sangat mengajarkan toleran dan hidup rukun dengan agama lain, seperti pada saat dilakukannya kegiatan keputrian peserta didik yang non islam mereka boleh tidak masuk kelas akan tetepi harus menjaga ketenangan, namun dalam observasi yang dilakukan peneliti ada saja peserta didik yang non islam mengikuti 
kegiatan keputrian tanpa paksaan, saat ditanya kenapa mengikuti kegiatan keputrian mereka menjawab karena ingin mendengarkan saja dan memang kegiatan keputrian diadakan untuk peempuan yang materinya berisi bagaimana cara menjadi seorang wanita yang baik menurut pandangan islam, peserta didik yang beragama islam menyambutnya dengan baik. Pada saat kegiatan BTQ juga SMA ini mengizinkan untuk yang non islam berangkat lebih siang pada hari jum'at, karena pada pelajaran satu jam pertama digunakan untuk melaksanakan program BTQ untuk memperbaiki cara membaca Al-Qur'an dengan benar.

Program infak atau shodaqoh diadakan setiap 3 kali seminggu yang berjalan dengan rutin dan tetib, hasil dari infak tersebut benar-benar diaplikasikan untuk pembangunan masjid dua lantai di SMAN 2 Batu. Pembangunan masjid juga untuk menunjang program yang lain yang diadakan di SMA ini yaitu sholat berjamaah agar lebih khusyuk dalam melaksanakan sholat ditempat yang bersih, besar, dan nyaman.

Program manasik haji yang dilaksanakan setahun sekali juga berjalan dengan lancar, program ini juga bertujuan agar peserta didik mengetahui bagaimana cara berhaji dengan baik dan benar sesuai dengan tuntunan islam, yang haji itu sendiri adalah salah satu penyempurna rukun islam yang kelima.

Kantin kejujuran yang diadakan di SMAN 2 Batu ini juga berpengaruh besar terhadap karakter religius peserta didik terutama sifat jujur, karena mengajarkan peserta didik untuk jujur saat tidak ada yang tahu apakah dia jujur atau tidak selain dirinya sendiri dan ALLAH subhanallahu WaTa'ala. Walaupun dalampelaksanaannya peserta didik masih ditakut-takuti dengan adanya CCTV, namun guru mengaku bahwa CCTV tersebut tidak berfungsi.
Dalam penelitian ini peneliti mendapatkan bahwa program untuk membentuk karakter religius yang diadakan SMAN 2 Batu berhasil dan sesuai dengan teori yang ada, bahwa dengan melaksanakan program yang berkaitan dengan karakter religius peserta didik di SMAN 2 Batu dapat mempunyai karakter religius yang baik dan memiliki toleransi yang tinggi terhadap pemeluk agama lain serta hidup rukun dengan pemeluk agama lain, dan memiliki sikap jujur, tawaduk kepada ALLAH dan para guru, dalam keadaan ada orang ataupun tidak ada orang, karena mereka mengetahui bahwa ada ALLAH yang selalu mengawasi mereka.

\section{Program Pendidikan Karakter Disiplin yang Dikembangkan Di SMAN 2 Batu}

Berdasarkan analisis data yang telah di lakukan peneliti ditemukan program yang berkaitan dengan karakter disiplin di SMAN 2 Batu yaitu: program PLS (pengenalan lingkungan sekolah) pendidikan baris-berbaris yang bekerja kerjasama dengan TNI AD di Poltekat (politeknik angkatan darat) atau pusdik, mengumpulkan tugas tepat waktu (on time), kegiatan 5S (senyum, sapa, salam, sopan, dan santun), upacara bendera dan semua peraturan atau tata tertib yang dibuat sekolah guna untuk mendisiplinkan peserta didik.

Program pengenalan lingkungan sekolah atau yang lebih dikenal dengan sebutan PLS berguna untuk mengenalkan para peserta didik diawal masuk sekolah tentang sekolah yang akan ditempatinya, sekolah mengenalkan tentang visi misi sekolah, sarana prasarana sekolah, dan termasuk peraturan yang dibuat untuk mengatur peserta didik agar lebih disiplin selama menuntut ilmu di SMAN 2 Batu.

Pendidikan baris-berbaris yang diadakan oleh SMAN 2 Batu yang bekerja sama dengan TNI AD juga berhasil dalam 
pelaksanaannya terbukti saat peneliti melakukan observasi cara berbaris mereka saat upacara bendera sangat rapi dan disiplin tanpa harus dimarahi ataupun dibimbing lagi oleh guru.

Pada saat observasi yang dilakukan peneliti dari proses penyambutan peserta didik, baik guru dan peserta didik menerapkan program 5S (senyum, sapa, salam, sopan, dan santun), juga peneliti memperhatikan ada beberapa peserta didik yang merasa melakukan pelanggaran misal: ada peserta didik yang memakai seragam yang tidak sesuai dan perlengkapan atribut yang kurang lengkap, mereka langsung menuju ruang tatib untuk mengambil kartu pelanggaran sesuai pelanggarnnya, dan nantinya petugas tatib akan memasukkan data peserta didik yang melanggar ke database. Ini menunjukkan keberhasilan guru dalam mewujudkan karakter disiplin. Mengerjakan tugas tepat waktu juga membawa buku mata pelajaran yang akan digunakan dalam kegiatan belajar mengajar juga termasuk mendisiplinkan peserta didik secara tidak langsung, karena jika peserta didik tidak dapat mengerjakan tugas dengan tepat waktu atau tidak membawa buku mata pelajaran, guru akan memberikan hukuman, sebagai contoh saat peneliti mengikuti kegiatan belajar mengajar mata pelajaran PPKn, ada beberapa peserta didik yang tidak membawa buku UUD 1945, maka guru menghukum dengan membayar kas kelas, atau membeli langsung di koperasi siswa (Kopsis).

Peraturan merupakan komponen penting jika menginginkan peserta didik memiliki karakter disiplin, karena peraturan dibuat untuk mendisiplinkan. Ini sesuai dengan pendapat yang dikemukakan oleh Sinungan (Elfrindi dkk, 2012:80) bahwa "disiplin merupakan suatu keadaan tertentu di mana orang-orang yang bergabung dalam organisasi tunduk pada peraturanperaturan yang ada dengan rasa senang hati".
Dalam penelitian ini peneliti mendapatkan bahwa program untuk membentuk karakter disiplin yang diadakan SMAN 2 Batu berhasil dan sesuai dengan teori yang ada, bahwa dengan lebih awal mengenalkan kedisiplinan dan menaati seluruh peraturan atau tata tertib yang dibuat sebagai program untuk mewujudkan karakter disiplin peserta didik di SMAN 2 Batu peserta didik dapat mempunyai karakter disiplin yang baik dan kesadaran untuk selalu menaati seluruh aturan yang ada disekolah, itu menujukkan bahwa mereka dengan senang hati menaati peraturan yang ada disekolah.

\section{Bentuk Implementasi Dari Karakter Religius dan Disiplin Di SMAN 2 Batu}

Berdasarkan analisis data diatas, maka dapat disimpulkan bahwa bentuk implementasi dari karakter religius dan disiplin adalah: dengan niat, melakukan semaksimal mungkin semua program atau peraturan yang telah dibuat, pemaksaan, pembiasaan, dengan memahamkan bahwa pentingnya karakter religius dan disiplin, serta dengan melibatkan seluruh keluarga audam atau keluarga besar SMA 2. Dan memang peneliti melihat pelaksanaan dari program-program religius ataupun disiplin sangat teratur, perlahan tapi pasti, tegas, disiplin, rasa nasionalisme tinggi, integritasnya tinggi, semua guru dan peserta didik saling mengingatkan, dan baik guru maupun peserta didik mempunyai kesadaran yang baik dalam melaksanakan tugasnya masing-masing.

\section{Implementasi Karakter Religius}

Implementasi dari karakter religius di SMAN 2 Batu dilakukan dengan cara mempunyai niat baik guru maupun peserta didik, pembiasaan, serta melaksanakan semua program yang telah dibuat dengan semaksimal mungkin dan membiasakan peserta didik untuk melaksanakannya. Bentuk pelaksanaan dari program karakter religius yang diterapkan oleh SMAN 2 
Batu sesuai dengan faktor yang dapat mempenggaruhi karakter religius, yang karakter ini bisa didapatkan peserta didik jika mereka ditekan untuk melakukan kegiatan yang bisa menumbuhkan karakter religius itu sendiri, yang nantinya peserta didik akan terbiasa melakukannya, dan akhirnya terwujudlah karakter religius yang diinginkan sekolah.

Sesuai dengan faktor religius yang dipaparkan oleh Thouless (1971) tentang faktor yang mempengaruhi karakter religius: yang pertama yaitu faktor pendidikan atau pengajaran dan berbagai tekanan sosial, program religius yang diadakan SMA ini adalah sebagai pengajaran dan tekanan bagi peserta didik karena dalam implementasinya peserta didik ditekan untuk mengikuti setiap kegiatan keagamaan yang dibuat di SMAN 2 Batu, mau tidak mau mereka harus mengikutinya dan akhirnya peserta didik akan terbiasa melakukannya. Bahkan ada peserta didik yang mengakui bahwa dalam menerapkan suatu program dengan pemaksaan, karena dengan pemaksaan lama-kelamaan mereka akan terbiasa melakukkannya dan lamakelamaan mereka juga akan memiliki kesadaran bahwa program tersebut diadakan untuk mencapai tujuan yang diinginkan.

Yang kedua faktor pengalaman, dari faktor pertama tadi menyebabkan peserta didik secara tidak langsung akan memiliki pengalaman saat pelaksanaan kegiatan berlangsung, terutama pengalaman tentang keindahan keselaraan, kebaikan, konflik moral dan pengalaman emosional. Dalam pengalaman emosional ini bisa didapatkan pada saat peserta didik laki-laki mendengarkan khutbah pada saat jum'atan di masjid yang diadakan di SMA N 2 Batu, bagi perempuan karena tidak mengikiuti sholat jum'at maka bisa melalui pengajian dan mendengarkan ceramah-ceramah agama pada saat program keputrian. Peserta didik mengaku mendapatkan berbagai macam pengalaman dari kegiatan keagamaan yang akhirnya bisa menjadi bekal peserta didik untuk memecahkan permasalahan dalam kehidupannya.

Yang ketiga yaitu faktor yang timbul dari kebutuhan yang tidak terpenuhi, terutama kebutuhan tentang keamanan, cinta kasih, harga diri, dan ancaman, sebagai contoh di SMAN 2 Batu ini peserta didik saat mengalami ujian sekolah mereka akan memohon kepada ALLAH untuk mempermudah mereka dalam mengerjakan ujian tesebut, karena mereka terancam antara lulus atau tidak. Faktor ini didapatkan saat mengikuti pelajaran BTQ. BTQ tidak hanya mengajarkan bagaimana cara membaca dan menulis Al-Qur'an yang baik dan benar tatapi pemateri juga memberikan motivasi penguatan mental peserta didik secara rohani.

Yang terakhir yaitu faktor pemikiran, dalam program yang dikembangkan SMAN 2 Batu ini menuntut peserta didik untuk mengikuti kegiatan secara terusmenerus (ini adalah pembiasaan) yang akhirnya jika ada peserta didik yang kurang paham terhadap agamanya, lama-kelamaan dia akan berfikir dan akan ada pertanyaan dalam hatinya untuk mencari kebenaran dalam beragama. Yang akhirnya nanti dia akan mengetahui yang benar dan dia akan berusaha berakhlak sesuai dengan agama yang diyakininya, maka nantinya peserta didik dapat memiliki karakter religius yang baik. 
Tabel 1. Karakter Religius

\begin{tabular}{|c|c|c|}
\hline No & Program Religius & $\begin{array}{l}\text { Nilai yang terkandung } \\
\text { (Karakter Religius) }\end{array}$ \\
\hline 1 & Berdoa & Menambah keimanan dalam keyakinan \\
\hline 2 & Penyambutan Peserta Didik & Mengajarkan keramahan kepada sesame \\
\hline 3 & BTQ & $\begin{array}{l}\text { Mendekatkan diri kepada Allah dengan selalu membaca Al- } \\
\text { qur'an }\end{array}$ \\
\hline 4 & Keputrian & $\begin{array}{l}\text { Mengetahui adab-adab sebagai seorang muslimah sesuai Al- } \\
\text { qur'an dan Sunnah }\end{array}$ \\
\hline 5 & Sholat Berjamaah & $\begin{array}{l}\text { Taat kepada Allah dengan menaati semua perintahNya, } \\
\text { Silaturahmi setelah selesai sholat }\end{array}$ \\
\hline 6 & Infaq / Shodaqoh & Membiasakan membantu sesame \\
\hline 7 & Wisroh (Wisata Rohani) & Menambah keimanan dalam keyakinan \\
\hline 8 & Pekan Seni PAI & Mengetahui apa saja seni dalam agama \\
\hline 9 & Sanlat (Pesantren Kilat) & Menambah keimanan dalam keyakinan \\
\hline 10 & Baksos Panti Asuhan & Mengajarkan untuk membantu sesame \\
\hline 11 & Manasik Haji & Agar mengetahui cara berhaji dengan benar \\
\hline 12 & Kantin Kejujuran & $\begin{array}{l}\text { Mengajarkan kejujuran walaupun ada atau tidak ada orang } \\
\text { karena selalu ada Allah }\end{array}$ \\
\hline 13 & Qiroah & Memperbaiki bacaan Al-qur'an \\
\hline 14 & Banjari / Rebana & Rebana adalah alat yang diperbolehkan oleh Rasul \\
\hline 15 & Badan Dakwah & Menambah keimanan dalam keyakinan \\
\hline 16 & Adiwiyata & Menjaga lingkungan yang diamanahkan Allah \\
\hline 17 & Peringatan Hari Besar Islam & Mengetahui apa saja hari-hari besar dalam agama islam. \\
\hline
\end{tabular}

\section{Implementasi Karakter Disiplin}

Implementasi dari karakter disiplin di SMAN 2 Batu dilakukan dengan cara memiliki niat yang kuat dari guru maupun peserta didik, melaksanakan segala program yang telah dibuat dengan semaksimal mungkin dan membiasakan peserta didik untuk manaati peraturan yang telah dibuat oleh sekolah untuk mendisiplinkan peserta didik. Bentuk implementasi yang dilaksanakan oleh SMAN 2 Batu ini juga sesuai dengan faktor-faktor yang dapat mempengaruhi karakter disiplin. Dalam kedisiplinan terdapat faktor yang mempengaruhi karakter kedisiplinan, diantarnya adalah faktor intern dan faktor ekstern.

Yang pertama faktor intern mencakup faktor pembawaan, faktor kesadaran, faktor minat dan motivasi, dan faktor pola pikir. Dalam faktor intern ini jelas terlihat pada peserta didik di SMAN 2 Batu dibimbing oleh sekolah agar peserta didik sadar untuk apa program dan peraturan dibuat. Sesuai dengan pengakuan peserta didik tentang alasan mereka pentingnya program yang terkait karakter disiplin, dan mereka juga menerapkan setiap aturan yang dibuat. Dan juga seperti yang di katakan oleh petugas tatib bahwa mereka selalu memotivasi peserta didik yang melanggar peraturan untuk tidak mengulanginya dengan begitu peserta didik yang melanggar dan didekati dengan pendekatan yang baik, dan juga karena petugas tatib selalu dekat dan menyelami dunia peserta didik untuk mendapatkan jawaban atau alasan mengapa mereka melakukan pelanggaran. Dengan begitu mereka berfikir bahwa mereka diperhatikan, yang akan menyebabkan mereka tidak akan mengulangi perbuatanya.

Yang kedua faktor ekstren mencakup faktor contoh atau teladan, faktor nasihat, faktor latihan, faktor lingkungan, dan pengaruh kelompok. Dalam observasi yang dilakukan peneliti, guru yang ada di SMAN 2 Batu benar-benar bisa dijadikan contoh atau teladan untuk kedisiplinan ini. Dari kepala sekolah yang selalu terjun kelapangan untuk mengecek keadaan dan kondisi yang terjadi di sekolah untuk mendengarkan curhatan guru atau peserta didik tentang keluhan yang mereka rasakan tentang sarana prasarana atau program yang diadakan disekolah dengan itu kepala 
sekolah dapat memperbaiki hal-hal yang kurang, wakil kepala sekolah yang setiap jam pelajaran juga selalu berkeliling untuk melihat guru atau peserta didik yang terlambat atau tidak masuk, dan guru yang selalu perhatian kepada peserta didik yang terlihat kurang bersemangat atau peserta didik yang selalu melanggar peraturan. Dari atasan sampai yang dibawahnya bisa menjadi teladan dan nasihat bagi peserta didik.

Faktor nasehat, setiap peserta didik yang melanggar tidak hanya dihukum namun juga diberi nasehat oleh petugas tatib yang selalu friendly dengan peserta didik, para petugas tatib ini berusaha untuk tidak membuat peserta didik takut kepada mereka, karena sugesti diluar beranggapan bahwa petugas tatib itu keras dan jahat, ini juga sesuai dengan perkataan bapak "B" yaitu: “...Prinsip kami ditatib itu tidak ada kendala, tetapi dilapangan yaa ada saja mungkin, tapi kita berusaha menyelami ke dunia anak, mereka yang terlambat satu dua kali memang kita hukum, tapi serta merta setelah dihukum sudah, tapi kita dalami kenapa dia terlambat, kalau sudah ketemu kita ikut carikan solusi..." (W/B/03/11/2017). Ini membuktikan bahwa mereka juga memberikan nasehat kepada peserta didik walaupun peserta didik telah melanggar, ini juga menyebabkan peserta didik merasa dilindungi dan dianggap yang membuat kesadarannya terbuka dan membuatnya akan lebih disiplin dan taat aturan.

Faktor latihan, sikap peserta didik saat melakukan pelanggaran dengan senang hati dan kesadaran diri langsung menuju ruang tatib menunjukkan keberhasilan peraturan yang dibuat oleh sekolah yang dilakukan dengan faktor latihan terlebih dahulu yang akhirnya peserta didik lebih sadar dan disiplin, ini menyebabkan tugas tatib menjadi lebih ringan. Ini sesuai dengan yang dikatakan oleh bapak
"A" sebagai berikut: "kalau disiplin itu harus ada aturan yang menjaga supaya aturan kedisiplinan ini lebih tertib dan pembiasaan, karena kalau sudah tertib maka tidak perlu ada yang mengawasi, tapi kalau selagi ketertiban itu perlu ada pengkondisian maka perlu adanya petugas tata tertib" (W/A/03/11/2017).

Faktor Lingkungan, di SMAN 2 Batu semua guru berusaha menaati dan menjalankan peraturan yang ada, dan sebagian besar dari peserta didik juga sudah banyak menerapkan atau patuh terhadap aturan yang dibuat, maka jika ada peserta didik yang tidak menaati tata tertib, dia akan malu kepada peserta didik lain yang tidak melanggar dan akhirnya dia akan berusaha juga untuk menaati tata tertib.

Dan yang terakhir adalah Faktor Kelompok, tentu dalam kelompok kita berusaha melakukan apa yang kelompok mau dan inginkan, jika kita tidak melakukan aturan maka kita akan dikeluarkan dari kelompoktersebut.Dalamimplementasinya peserta didik di SMAN 2 Batu rata-rata mereka selalu menaati aturan, jika ada peserta didik yang tidak menaati aturan mereka akan saling menegur, akhirnya mereka tidak ada mengulangi hal tersebut, karena terkadang ada peserta didik yang dia tidak mau mendengarkan nasehat gurunya, tetapi dengan mudah melaksanakan yang dikatakan oleh temannya sendiri.

Dalam penelitian ini peneliti mendapatkan bahwa bentuk implementasi dari program untuk membentuk karakter religius dan disiplin yang diadakan SMAN 2 Batu berhasil dan sesuai dengan teori yang ada. Yaitu dengan cara memaksukkan faktor-faktor yang mempengaruhi karakter religius dan disiplin, dan membiasakan mereka untuk mengikuti seluruh program yang telah dibuat, karena membiasakan sesuatu yang baik dapat membentuk karakter yang baik pula. 


\begin{tabular}{|c|c|c|}
\hline No & Program Disiplin & $\begin{array}{l}\text { Nilai yang terkandung } \\
\text { (Karakter Disiplin) }\end{array}$ \\
\hline 1 & $\begin{array}{l}\text { PLS (Pengenalan } \\
\text { Lingkungan Sekolah) }\end{array}$ & $\begin{array}{l}\text { Agar beradaptasi ditempat baru yang akhirnya bisa } \\
\text { mengetahui cara disiplin sesuai tempatnya }\end{array}$ \\
\hline 2 & Baris-berbaris & $\begin{array}{l}\text { Agar mudah diatur tidak perlu diingatkan lagi oleh } \\
\text { petugas saat ada acara baris-berbaris }\end{array}$ \\
\hline 3 & $\begin{array}{l}\text { Mengumpulkan tugas tepat } \\
\text { waktu (on time) }\end{array}$ & Agar terbiasa disiplin tepat waktu \\
\hline 4 & $5 \mathrm{~S}$ & $\begin{array}{l}\text { Mendisiplinkan peserta didik dengan harus mematuhi } \\
\text { segala program sekolah }\end{array}$ \\
\hline 5 & Upacara bendera & $\begin{array}{l}\text { Agar selalu tertib tepat waktu datang ditempat upacara, } \\
\text { tertib sesuai urutan kelas, disiplin dalam melengkapi } \\
\text { atribut seragam (akhirnya nanti peserta didik akan } \\
\text { disiplin dalam segala hal tepat waktu dan patuh) }\end{array}$ \\
\hline 6 & Peraturan Tata Tertib & $\begin{array}{l}\text { Mendisiplinkan semua tingkah laku peserta didik sesuai } \\
\text { aturan }\end{array}$ \\
\hline
\end{tabular}

\section{SIMPULAN}

Berdasarkan analisis data diatas maka peranan sekolah dalam membentuk karakter religius dan disiplin peserta didik di SMAN 2 Batu dapat ditarik kesimpulan bahwa: Program pendidikan karakter religius yang dikembangkan di SMAN 2 Batu berjalan sesuai rencana, programprogram tersebut adalah: Berdoa sebelum melakukan pembelajaran, Penyambutan siswa, BTQ, keputrian, sholat berjamaah, infaq/shodaqoh, wisroh (wisata rohani islam), pekan seni PAI, sanlat (pesantren kilat), baksos panti asuhan, manasik haji (setahun sekali), kantin kejujuran, qiroah, banjari/rebana, BD (Badan Dakwah), Adiwiyata, peringatan hari besar agama seperti idul adha, idul fitri, halal bihalal, isra' miraj, dan pendalaman tentang agama oleh guru-guru mata pelajaran. Program pendidikan karakter disiplin yang dikembangkan di SMAN 2 Batu berjalan sesuai rencana, program-program tersebut adalah: program PLS (pengenalan lingkungan sekolah) pendidikan barisberbaris yangbekerjakerjasama dengan TNI AD di Poltekat (politeknik angkatan darat) atau pusdik, mengumpulkan tugas tepat waktu (on time) kegiatan 5S (senyum, sapa, salam, sopan, dan santun), upacara bendera dan semua peraturan atau tata tertib yang dibuat sekolah guna untuk mendisiplinkan peserta didik. Bentuk implementasi dari karakter religius dan disiplin peserta didik di SMAN 2 Batu berjalan sesuai rencana, dengan implementasi sebagai berikut: dengan niat, melakukan semaksimal mungkin semua program atau peraturan yang telah dibuat, pemaksaan, pembiasaan, dengan memahamkan bahwa pentingnya karakter religius dan disiplin, serta dengan melibatkan seluruh keluarga besar SMAN 2 Batu.

\section{DAFTAR PUSTAKA}

---------,Undang-Undang Republik Indonesia No. 20 Tahun 2003 Tentang Sistem Pendidikan Nasional.

Hidayatullah, M. Furqon. 2010. Pendidikan Karakter: Membangun Peradaban Bangsa. Surakarta: Yuma Pustaka.

Kemendiknas. 2010. Pengembangan pendidikan Budaya dan Karakter Bangsa. Jakarta: Kementerian Pendidikan Nasional.

Ramli, T. (2003). Pengertian Pendidikan Karakter. (Online) http://blog.condingwear. com/bacaan-99-pengertian-karakter.html diakses tanggal 26 Desember 2017

Subari. 1994 Supervisi Pendidikan dalam Rangka Perbaikan Situasi Mengajar. Jakarta: Bumi Aksara.

Suparlan. 2010. Pendidikan Karakter: Sedemikian Pentingkah dan Apa yang Harus Kita Lakukan. (Online), 
http://www.suparlan.com, diakses 26 Desember 2017.

Syaiful Bahri Djamarah, 2002. Rahasia

Sukses Belajar. Jakarta : Rineka Cipta.

Thomas Lickona, 1992. Educating For Character: How Our School Can Teach Respect and Responsibility. New York : Bantam Books
Thouless, Robert Henry. 1971. An introduction to the psychology of religion. London: Cambridge University Press.

Zuriah, Nurul. 2017. Rekayasa Sosial Model Pendidikan Karakter Bagi Penguatan Kewarganegaraan Multikultural di Perguruan Tinggi. (online) ppkn.umpo. ac.id/wp-content/uploads/2017/08/15NURUL-ZURIAH.pdf diakses tanggal 18 februari 2018 